\title{
Money Market Instruments and Growth of the Nigerian Economy: An Empirical Analysis
}

\author{
Akarara Ebierinyo Ayebaemi ${ }^{1}$ and Eniekezimene A. Francis ${ }^{2}$ \\ ${ }^{1}$ Department of Economics, Niger Delta University, Wilberforce Island, Bayelsa State, \\ Nigeria. \\ Email: ebierinyo@gmail.com \\ Contact: +2348037892022 \\ ${ }^{2}$ Department of Economics, Niger Delta University, Wilberforce Island, Bayelsa State, \\ Nigeria.
}

\begin{abstract}
This paper investigated the effect of selected money market instruments on the growth of the Nigerian economy. Using data obtained from Central Bank of Nigeria Statistical Bulletin 2017, the study employed the Autoregressive Distributive Lag (ARDL) Bound Testing approach to co-integration. Result shows no form of convergence among the variables in the long-run. It also revealed that money market variables are positively related with economic growth rate both in the short and long-run, except for Certificate of Deposit (COD) and Commercial Paper $(C P R)$ that has an inverse relationship with economic growth in the longrun. Broad Money Supply $(M 2 G)$ does not seem to have a significant relationship with GDPR both in the short and long-run, while Treasury Certificate (TRC) has a significant positive impact on GDPR in the short-run but an insignificant impact on GDPR in the long-run. Thus, caution should be taken by the Central Bank of Nigeria in the use of Treasury Certificate as a means of managing liquidity in the short-run, as its prolonged use would amount to no significant effect in the economy. Also, Certificate of Deposit and Commercial Paper should be used on short term basis, if otherwise; their impact on the economy would be negative.
\end{abstract}

Keywords: Money Market, Economic Growth, Certificate of Deposit, Commercial Paper, Money Supply, Treasury Certificate, ARDL

\section{Introduction}

The importance of the financial sector/system of any economy can never be overemphasized as acts as the oil that lubricates the several components of the economy. Thus, the functionality and growth of an economy depends largely on it. The function of the financial sector of every economy is to co-ordinate the activities of both the surplus and deficit economic units and process is referred to as "the financial intermediation role" of financial 
institutions (Edoumiekumo and Akarara, 2016). Financial system consists of financial institutions and markets that regulate the flow of funds through the macro-economy of the country (Nwude, 2004).

The financial market is an important component of any financial system of any economy in the world (Nigeria inclusive) and is comprised of the capital and money markets. While the capital market serves as a mechanism by which the savings of surplus economic units may be used to finance medium and long term investments, the money market primarily exists as a means of liquidity adjustment (Eniekezimene, 2011). Afolabi (1991) attributes this obvious difference to the level of liquidity of the instruments traded in both markets.

The focal point of this paper is the money market which forms an integral part of the financial market where securities and financial assets with high liquidity and short term maturity periods are traded. The Nigerian money market through banking activities is expected to impact positively on the economic growth of a country, as it plays a vital role in managing liquidity and acts the conduit that transmits the nation's monetary policy (Eniekezimene, 2011). It also provides the appropriate instruments for liquidity trading through the alleviation of liquidity risks associated with businesses and also provide the environment for short and medium term loan refinancing. Pedro and Erwan (2004) also share this view as the affirm that the activities of the money market raise output in developed economies by increasing the working capital used in production, and ensure the availability of capital and at a relatively low cost. Thus, an efficient and functional money market is an essential tool for the growth of the economy.

According to Nnanna and Dogo (1998), Fakiyesi and Akano (2005), Akinlo and Olufisayo, (2007), Edo and Ikelegbe (2014), it will be erroneous to state that the Nigerian money market has lived up to its expectations since inception compared to money markets of developed economies. They agreed there has been a significant improvement in the operations of the Nigerian money market since 1986 when the financial system was liberalized, but suggested further improvement in the industry as it is characterized with operational inefficiency, low capital base, the absence of efficient and cost effective system for transferring ownership of securities in a repurchase transaction of the secondary money market, as well as the delay of payment to owners of securities in same market. Other problems of the market include; weak domestic payment systems, dearth of private sector instruments, shortage of trained/experienced operators, excessive interest rate margins and a high level of corruption in the market. It is against this against this backdrop that this paper 
seeks to investigate the impact of selected money market instruments on economic growth in Nigeria with the aim of testing the following hypotheses.

- Treasury Certificate has not significant impacted on economic growth in Nigeria.

- Commercial Paper has not significant impacted on economic growth in Nigeria.

- Certificate of Deposits has not significant impacted on economic growth in Nigeria.

\section{Theoretical Framework/Literature Review}

In recent times, studies on the money market and economic growth have been is anchored to the Quantity Theory of Money. The quantity theory of money remains one of the oldest economic doctrines; it states that changes in the general level of prices are determined by changes in the quantity of money in circulation, or money stock. This theory was developed by Jean Bodin, a French social philosopher. According to the theory when money becomes abundant, its value or purchasing power falls, and consequently the prices of commodities rises, and vice versa. The quantity theory of money was further developed by John Locke, who added that the changes between the increase of money in circulation and changes in prices are in direct proportion. Thus, a 10\% increase in the money stock or money in circulation leads to $10 \%$ in the general level of prices of commodities. This theory is closely associated with inflation. Inflation in its simplest term means a galloping rise in the general price level resulting from an excessive rise in the quantity of money in circulation. Onovkwe cited in Ezirim and Eneka (2006) attributed inflation to increase in money supply. Monetary authority employing money market instruments formulate policy to curb or control inflation for economic growth of a country.

\section{A. The Loanable Funds Theory of Interest}

The neo-classical or loanable funds theory explains the determination of the rate of interest in terms of the demand and supply for loanable funds or credit. For this theory, the interest rate is the 'Price of Credit' which a function of the demand and supply of funds. The Price equates the supply of credit or savings plus the net increase in the amount of money in a period to the Demand for credit or investment plus the net hoarding in the period.

The impact of the money market in any economy has continued to generate debates, hence a number of studies have evolved over the years. Among the leading studies on money market and its impact in the economy is the work by Iwedi and Igbanibo (2015) on the Nexus between Money Market Operations and Economic Growth in Nigeria, using Ordinary Least Squares and Johansen Cointegration Test methods revealed that in both long and short run there existed a positive significant relationship between money market variables (instruments) 
and Nigerian economic development for the periods 1980 - 2013. This means that market operations have strong connection on the level of economic activities in Nigeria. Thus, as these operations improve, the economy also tends to improve by the same proportion. However, the study of Iwedi and Igbanibo recommended that, there should be in place sound macroeconomic policies to the functionality of existing money market should be strengthened through dissemination of information in the market.

Muhammad, Berly and Andi (2015) in carrying out a study on The Contribution of Savings and Loans on GDP Growth: The Case of Indonesia (2002 - 2012), employed the generalized least square technique with dependent variable (GDP) and independent variables (Savings and Loans); found that savings and loans have significant effects on GDP. Thus, savings and loan can promote better economic performance of Indonesian economy. In addition, the study discovered that foreign direct investment (FDI) has a positive significant effect on GDP, while domestic direct investment (DDI) has a negative significant influence on GDP.

Ezirim and Eneta (2006) in their study on discount houses, the money market and the Nigeria economy, examined the operations of discount houses in Nigeria economy in general covering the period 1993 to 2004 . They used regression analyses in their investigation covering 5 discount houses in Nigeria. They found a significant positive relationship between the independent and dependent variables. They concluded that discount houses operations in Nigeria affect the Nigeria money market and economy both positively and significantly.

According to Ihsan and Anjum (2013) in their study, Impact of money supply $\left(\mathrm{M}_{2}\right)$ on GDP in Pakistan (2000 - 2011), adopting the multiple regression technique, and using GDP as its independent variable, while inflation rate, interest rate and Consumer Price Index (CPI) served as independent variables. It was found that, money supply $\left(\mathbf{M}_{2}\right)$ impacted on GDP, as interest rate and CPI had a significant impact on GDP in Pakistan. They recommended that money supply needs aggressive control to boost the economy.

According to Andrew and Deborah (2015), using the multiple regression technique, Pearson correction coefficient and ANOVA to investigate Development in Money Market Operations and Economic Viability in Nigeria. With data taken between 1981 and 2011, they found that from Pearson correction coefficient there exist a strong robust linear relationship between Gross Domestic Product (GDP) and Money Market Instruments (Treasury bill, Treasury certificate, Certificate of deposit, Commercial paper and Bankers' acceptance). 
Also, Ogunmuyiwa and Ekone (2010) in their conducted study on Money Supply Economic Growth Nexus in Nigeria (1980 - 2006), adopting Ordinary Least Square, Vector Auto Regression Technique and Granger Causality Test revealed that money supply has a positive relationship with economic growth and development, but does not have a significant predictive power in explaining the growth of real GDP.

Chris and Anyingang (2012) in their study The Effect of Interest Rate on the Economic Growth of Nigeria (1970-2010) employed the Ordinary least square multiple regression technique, discovered that there economic growth of the real sector and interest rate has a negative relationship. This means as interest rate rises economic growth drops because of the fall in output caused by the fall in productive activities resulting from the cost of securing funds. On the other hand, the study revealed, that as interest rate savings will also increase thereby inducing growth in the economy.

Although the various empirical literature [Andrew and Deborah (2015), Iwedi and Igbanibo (2015), and Ezirim and Eneta (2006)] established a positive impact of money market on the economy, this study sought to ascertain if the money market still has a significant impact on the economy in this present time, owing to the fact that a lot has occurred in the Nigerian economy with the emergence of a new government which has introduced its own economic policies.

\section{Methodology and Data}

Data for the analysis in this paper are annual data covering the period 1981-2017, obtained from the Central Bank of Nigeria (CBN) statistical bulletin 2017 edition. The paper employed various statistical and econometrics tools to investigate the impact of the money market on economic growth in Nigeria. Thus, different variables associated with the functionality of the money market have been included as regressors to economic growth. The variables are Treasury Certificate (TRC), Certificate of Deposit (COD), Commercial Paper (CPR), and Broad Money Supply growth (M2G) which is regressed against economic growth (GDPR). These variables were selected because of their relevance to money market and economic growth. The study adopted the Autoregressive Distributed Lag (ARDL/Bounds testing) Approach.

The usefulness of the ARDL model for the estimation of level relationships was emphasized by Pesaran, Shin and Smith (2001) as it suggests that the relationship can be estimated using OLS once the order of the ARDL is recognized. The ARDL model also makes provision for incorporating variables that are integrated of me (1) and me (0) as 
behavioral variables. Thus, this technique does not require a specific identification of the order of the underlying data. Taking clue from Pesaran et al. (2001), the vector autoregressive (VAR) of order $p$, denoted VAR ( $p$ ), for the following growth function is specified:

$Q_{t}=\alpha+Q_{t-i}+\sum_{i=1}^{m} \mu_{1} y_{t-i}+\sum_{i=1}^{m} \mu_{2} x_{t-i}+u_{t}$

Where $Q_{t}$ is the vector of both $x_{t}$ and $y_{t}, y_{t}$ is the regresand (GDPR), $x_{t}$ represents the vector of regressors i.e., Treasury Certificate (TRC), Certificate of Deposit (COD), Commercial Paper (CPR), and Broad Money Supply growth (M2G), and $t$ is a trend variable. According to Pesaran et al. (2001), $y_{t}$ must be integrated after differencing once, that is, $y_{t}$ (GDPR) must be stationary at first difference, but the regressors $x_{t}$ can be stationary either at $\mathrm{I}(0)$ or $\mathrm{I}(1)$. A vector Autoregressive model is further specified as follows:

$$
\Delta Q_{t}=\alpha+\lambda Q_{t-1}+\sum_{i=1}^{m-i} \mu_{t} \Delta y_{t-i}+\sum_{i=1}^{m-1} \mu_{t} \Delta x_{t-i}+\varepsilon_{t}
$$

Where; $\Delta=\mathrm{I}$ (1) operator. The long-run multiplier matrix of the both the regresand and regressors is given as:

$$
\eta=\left[\begin{array}{l}
\eta_{Y Y} \eta_{Y X} \\
\eta_{X Y} \eta_{X X}
\end{array}\right]
$$

The unrestricted regressors are captured on the diagonal of the matrix, so they can integrated of order I (0) or I (1). When $\rho_{Y Y}=0$, then $y$ (GDPR) is stationary after differencing once [i.e of order I (1)] but, if it is less than zero, then $y$ is stationary at level [i.e, I (0)]. Equation 2 is required to ascertain if the existence of at least one co-integrating relationship between the dependent variable $y_{t}$ (GDPR) and the set of regressors $x_{t}$ (TRC, COD, CPR, M2G). The test hypothesis for the $y_{t}$ equation is;

$$
\mathrm{H}_{0}: \rho_{\mathrm{yy}}=\rho_{\mathrm{yx}}=0 \text { (nolong }- \text { runrelationship) }
$$

Against the alternate

$$
\mathrm{H}_{\mathrm{A}}: \rho_{\mathrm{yy}} \neq \rho_{\mathrm{yx}} \neq 0 \text { (along - runrelationshipexists) }
$$

Similarly, the corresponding test hypothesis for the $x_{t}$ equation is obtainable from the long-run multiplier matrix and it can be stated in the form of an Unrestricted Error Correction Model (UECM) in equation 3 below. 


$$
\begin{aligned}
& \Delta(G D P R)_{t}=\beta_{0}+\beta_{1}(G D P R)_{t-1}+\beta_{2}(C O D)_{t-1}+\beta_{3}(T R C)_{t-1}+\beta_{4}(C P R)_{t-1}+\beta_{5}(M 2 G)_{t-1}+ \\
& \sum_{i=1}^{p} \beta_{6} \Delta(G D P R)_{t-i}+\sum_{i=0}^{q} \beta_{7} \Delta(C O D)_{t-i}+\sum_{i=0}^{r} \beta_{8} \Delta(T R C)_{t-i}+\sum_{i=0}^{s} \beta_{9} \Delta(C P R)_{t-i}+ \\
& \sum_{i=0}^{t} \beta_{10} \Delta(M 2 G)_{t-i}+\varepsilon_{t}
\end{aligned}
$$

Where $\Delta$ is the first-difference operator and $\varepsilon_{t}$ is the stochastic term, GDPR, COD, TRC, CPR, and M2G are as defined above.

Equation (3) above is the ARDL model of order ( $p, q, r, s$ and $t)$ and indicates that GDPR tends to be influenced and explained by its past values. The Akaike's information criteria (AIC) are used to select the lag structure of the model. The long run elasticities of the model is obtained by dividing the product of the coefficient of one lagged explanatory variable and a negative sign by the coefficient of one lagged dependent variable (Bardsen, cited in Roa, et al. 2010), while the short-run effects are represented by $\beta_{1,} \beta_{2,} \beta_{3,} \beta_{4}$, and $\beta_{5}$ in Equation 3.

After estimating Equation (3), the Wald test (F-statistic) is computed to distinguish the long-run relationship between the variables of interest. This done by imposing restrictions on the long run estimated coefficients of the variables concerned.

According to Pesaran et al. (2001), if the computed $F$-statistic is lesser than the lower bound value, then the null hypothesis of no long run relation is not rejected and we can conclude that money market instruments and economic growth do not share any co integrating vector. On the other hand, if the computed $F$-statistic is greater than the upper bound value, then, money market and economic growth share common relationship in the long run.

\section{Data Analysis and Discussion of Results}

The descriptive statistics and the combined line graph of the variables presented in Table 1 showed that for the period under review the mean GDP growth rate, Treasury Certificate, Certificate of Deposit, Commercial Paper, and Broad Money Supply growth was $4.14,8.78,9.16,86.40$ and 23.99 percent per annum. This is a clear indication that all the other variables (especially Commercial Paper) has been growing faster than GDPR on the average. This trend can also be seen in Figure 1 where the combined time plot showed that COD is far above GDPR. Also, the distribution in table 1 also indicates that GDPR is negatively skewed while COD, CPR, M2G and TRC are positively skewed. The kurtosis 
Pakistan Journal of Humanities and Social Sciences, 6(1), 2018

statistics reveal that all the distribution is leptokurtic except for $\mathrm{M} 2 \mathrm{G}$, resulting in Jarque Bera statistics of $16.89,11.24,3.53,2.19$ and 3.14. This is an evidence that the series is not normally distributed, thus suggesting that the series may be exhibiting a random walk. However, to ascertain the true data generating process, the Augmented Dickey - Fuller unit root test is estimated.

Table 1: Descriptive Statistics

\begin{tabular}{|l|c|c|c|c|c|}
\hline & COD & CPR & GDPR & M2G & TRC \\
\hline Mean & 9.163636 & 86.40303 & 4.145455 & 23.99333 & 8.784848 \\
\hline Median & 0.200000 & 10.00000 & 4.600000 & 21.55000 & 0.000000 \\
\hline Maximum & 142.1000 & 822.7000 & 10.00000 & 57.78000 & 39.70000 \\
\hline Minimum & 0.000000 & 0.100000 & -5.400000 & 1.200000 & 0.000000 \\
\hline Std. Dev. & 28.05041 & 175.8087 & 3.739827 & 15.85486 & 13.91623 \\
\hline Skewness & 3.703829 & 2.858106 & -0.828658 & 0.475430 & 1.371829 \\
\hline Kurtosis & 16.89133 & 11.24020 & 3.532449 & 2.186656 & 3.135094 \\
\hline Jarque-Bera & 340.7835 & 138.2920 & 4.166520 & 2.152790 & 10.37562 \\
\hline Probability & 0.000000 & 0.000000 & 0.124524 & 0.340822 & 0.005584 \\
\hline
\end{tabular}

Source: Authors' Computation

Figure 1: Trend Analysis of money market instruments and Economic Growth rate in Nigeria from 1981 to 2017

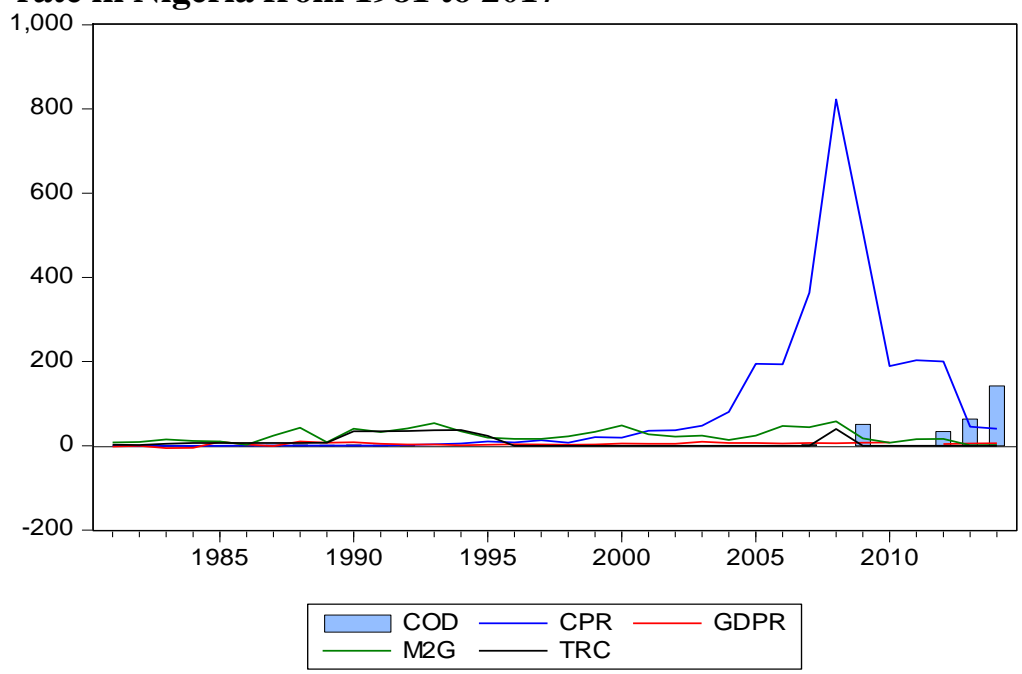

\section{Results and Discussion}

In other to stationarize the random walk exhibited by the series in this study, the Augmented Dick-Fuller (ADF) unit root test was carried out and the result is presented in table 2 below. It 
is important to note here that the lag length for estimating the ADF below is automatic based on SIC, and with maximum lag length of 8.

Table 2: ADF unit root test result

\begin{tabular}{|c|c|c|c|c|c|}
\hline \multirow{2}{*}{ Variable } & \multicolumn{2}{|c|}{ ADF - Statistic } & \multirow{2}{*}{ Model } & $\begin{array}{c}\text { 5\% Critical } \\
\text { Values }\end{array}$ & \multirow{2}{*}{$\mathbf{I}(\mathbf{d})$} \\
\cline { 2 - 3 } & Level & $\mathbf{1}^{\text {st }}$ Difference & & & \\
\hline GDPR & -1.733 & -7.424 & Trend & -3.568 & $\mathrm{I}(1)$ \\
COD & -6.54 & - & Trend & -3.574 & $\mathrm{I}(0)$ \\
CPR & -3.797 & - & Trend & -3.595 & $\mathrm{I}(0)$ \\
M2G & -3.004 & -6.984 & Trend & -3.558 & $\mathrm{I}(1)$ \\
TRC & -2.847 & -7.148 & Trend & -3.558 & $\mathrm{I}(1)$ \\
\hline
\end{tabular}

Source: Authors' Computation

The result in table 2 above show that GDPR, M2G and TRC became stationary after differencing once, COD and CPR were stationary at level. The result clearly shows a combination of order zero or I( 0$)$ and order one or I(1), thus, the Johansen's cointegration test cannot be conducted at this point as important assumption of the test has been violated, thus both the Engle-Granger and the Johansen's techniques are broken. This is a clear indication that the Autoregressive Distributed Lag (Bounds Testing) approach to cointegration is more suitable for analyses in this study. The result of the Bounds Test is presented below in table 3 .

Table 3: ARDL Bounds Test

\begin{tabular}{|c|c|c|}
\hline Test Statistic & Value & K \\
\hline F-statistic & 3.078127 & 4 \\
\hline \multicolumn{3}{|c|}{ Critical Value Bounds } \\
\hline Significance & I0 Bound & I1 Bound \\
\hline $10 \%$ & 2.45 & 3.52 \\
\hline $5 \%$ & 2.86 & 4.01 \\
\hline $2.5 \%$ & 3.25 & 4.49 \\
\hline $1 \%$ & 3.74 & 5.06 \\
\hline
\end{tabular}

Note: Null Hypothesis: No long-run relationships exist

Table 3a: Test Equation

\begin{tabular}{|c|c|c|c|c|}
\hline \multicolumn{5}{|c|}{ Dependent Variable: D(GDPR) } \\
\hline Variable & Coefficient & Std. Error & t-Statistic & Prob. \\
\hline D(GDPR(-1)) & -0.605837 & 0.293702 & -2.062761 & 0.0346 \\
\hline D(GDPR(-2)) & -0.982094 & 0.769996 & -1.275453 & 0.4233 \\
\hline D(GDPR(-3)) & -0.532547 & 0.785565 & -0.677916 & 0.6207 \\
\hline D(COD) & 0.823944 & 0.323286 & 2.548654 & 0.0134 \\
\hline D(COD(-1)) & 11.24936 & 10.95379 & 1.026984 & 0.4915 \\
\hline
\end{tabular}




\begin{tabular}{|c|c|c|c|c|}
\hline $\mathrm{D}(\operatorname{COD}(-2))$ & 10.15285 & 9.341905 & 1.086807 & 0.4735 \\
\hline $\mathrm{D}(\operatorname{COD}(-3))$ & 3.427466 & 7.568371 & 0.452867 & 0.7293 \\
\hline D(CPR) & 0.037374 & 0.056649 & 0.659753 & 0.6287 \\
\hline $\mathrm{D}(\mathrm{CPR}(-1))$ & 0.290557 & 0.477576 & 0.608399 & 0.6520 \\
\hline $\mathrm{D}(\mathrm{CPR}(-2))$ & 0.327187 & 0.451852 & 0.724101 & 0.6010 \\
\hline $\mathrm{D}(\mathrm{CPR}(-3))$ & 0.084505 & 0.263688 & 0.320473 & 0.8026 \\
\hline D(M2G) & 0.024787 & 0.158294 & 0.156590 & 0.9011 \\
\hline D(M2G(-1)) & -0.178218 & 0.262277 & -0.679502 & 0.6200 \\
\hline $\mathrm{D}(\mathrm{M} 2 \mathrm{G}(-2))$ & -0.190923 & 0.195359 & -0.977295 & 0.5073 \\
\hline D(M2G(-3)) & -0.076763 & 0.202187 & -0.379664 & 0.7690 \\
\hline D(TRC) & 0.341495 & 0.159731 & 2.137982 & 0.0240 \\
\hline D(TRC(-1)) & 0.321244 & 0.283698 & 1.132347 & 0.4605 \\
\hline D(TRC(-2)) & 0.133004 & 0.157597 & 0.843950 & 0.5537 \\
\hline D(TRC(-3)) & 0.169647 & 0.124375 & 1.363995 & 0.4027 \\
\hline Constant & 8.042183 & 5.756714 & 1.397009 & 0.3955 \\
\hline $\operatorname{COD}(-1)$ & -8.630464 & 9.860298 & -0.875274 & 0.5423 \\
\hline CPR(-1) & -0.266197 & 0.391636 & -0.679706 & 0.6200 \\
\hline M2G(-1) & 0.057507 & 0.345205 & 0.166588 & 0.8949 \\
\hline TRC(-1) & 0.046735 & 0.383762 & 0.121781 & 0.9229 \\
\hline $\operatorname{GDPR}(-1)$ & -0.645937 & 0.823656 & -0.784232 & 0.5766 \\
\hline
\end{tabular}

Note: $\mathrm{R}^{2}=0.814$, Adjusted $\mathrm{R}^{2}=0.604, \mathrm{~S} . \mathrm{E}=2.242, \mathrm{~F}$-statistic $=4.647$, Prob (F-statistic) $=0.00$, DW stat. $=2.873$, Source: Authors' computation

The result in table 3 show that a long-run relationship does not exist between the various money market instruments and economic growth in Nigeria since, the Wald F-statistic (3.078127) is less than the upper bound critical value (4.01) at 5 percent. The value of the coefficient of GDPR lagged in the first period measures the speed of adjustment of the model to long-run equilibrium, it is negative as expected and it is statistically significant. This shows that if there are short-run fluctuations that cause economic growth to deviate from its equilibrium path, it will return at the speed of $61 \%$ per annum. This means that it will take approximately a year and six months for GDPR to return to its equilibrium path peradventure there are any short-run fluctuations that cause it to wander away. Table 3 also reveals that at a $1 \%$ short-run increase in the value of COD, GDP growth rate would increase by 0.82 percent 
and this is statistically significant at the 5 percent level. Thus, hypothesis 3 above is rejected and its alternate accepted. Meaning that certificate of deposit is an effective monetary policy instrument in Nigeria in the short-run. However, the long-run coefficient of -13.361162 shows that in the long-run, a percentage increase in COD, retards real GDP growth by approximately 13.4 percent (see table 4). On the other hand, all the lagged differenced short-run coefficients of COD is not statistically significant at the 5\% level, meaning that COD does not impacts on economic growth with time lag. CPR is also positively related with economic growth in the short-run but is negatively related in the long-run. Its impact is statistically insignificant both in the short-run and long run. With this, hypothesis 2 above is accepted and its alternate rejected. The coefficient of 0.037374 shows that a $1 \%$ increase in CPR would result to approximately $0.04 \%$ increase in GDP growth rate. The lagged differenced short-run coefficient of inflation is also statistically insignificant at the 5 percent level, meaning that CPR does not also impact on economic growth with time lag (see table 3 and 4). M2G also has a positive impact on economic growth both in the short and long-run but this impact is not statistically significant, (see table 3 and 4). Meaning that both in the short-run and long-run, increase in $\mathrm{M} 2 \mathrm{G}$ would result to growth in the economy and it does not impact significantly on economic growth with time lag.

Table 4: ARDL Co integrating and Long Run Form

\begin{tabular}{|c|c|c|c|c|}
\hline \multicolumn{5}{|c|}{ Dependent Variable: GDPR } \\
\hline \multicolumn{5}{|c|}{ Co integrating Form } \\
\hline \multicolumn{5}{|c|}{ Long Run Coefficients } \\
\hline \multicolumn{5}{|c|}{$0.0724 *$ TRC +12.4504$)$} \\
\hline Variable & Coefficient & Std. Error & t-Statistic & Prob. \\
\hline COD & -13.361162 & 24.476095 & -0.545886 & 0.6819 \\
\hline CPR & -0.412111 & 0.901219 & -0.457281 & 0.7270 \\
\hline M2G & 0.089029 & 0.470744 & 0.189124 & 0.8810 \\
\hline TRC & 0.072352 & 0.599240 & 0.120740 & 0.9235 \\
\hline Constant & 12.450423 & 23.410601 & 0.531828 & 0.6888 \\
\hline
\end{tabular}

Source: Author's Computation

The results in table 3 and 4 reveal that TRC is positively related with GDPR both in the short-run and long-run. This impact is statistically significant in the short-run but insignificant in the long-run. Meaning that as TRC keeps increasing, its impact on economic growth tend to fade out until it becomes insignificant in the long-run. Since TRC is significant in the short-run, hypothesis 1 above is rejected and it alternate accepted. The Adjusted R- 
squared value of 0.604 shows that about $60 \%$ of the behavior of economic growth is explained by the regressors in the model. The overall model is also statistically significant judging by the F-statistic value of 4.647 and its probability value of 0.004 (See Table 3). The Correlogram of Residuals Squared statistics for autocorrelation showed no evidence of auto or partial correlation since the probability values are statistically not significant at the 5\% level (see results in appendix).

\section{Conclusion and Recommendations}

This paper conclude that all the money market variables adopted in the study are positively related with economic growth rate in the short-run and long-run except for Certificate of Deposit (COD) and Commercial Paper (CPR) that has an inverse relationship with economic growth in the long-run. COD has a positive significant relationship with GDPR in the short-run; the same cannot be said of it in the long-run. CPR on the other hand does not have a significant relationship with GDPR both in the short and long-run and does not also impact significantly on GDPR with time lag. The same is true of M2G, while TRC has a significant positive impact on GDPR in the short-run but an insignificant impact on GDPR in the long-run. This is a clear indication that the Nigerian money market has not truly been efficient in carrying out it functions. Thus, it is recommended that caution should be taken by the Central Bank of Nigeria in the use of Treasury Certificate as a means of managing liquidity in the short-run, as its prolonged use would amount to no significant effect in the economy. Also, Certificate of Deposit and Commercial Paper should be used on short term basis, if otherwise; their impact on the economy would be negative. 


\section{Reference}

Afolabi, L. (1991). Monetary Economics. Heinemann Educational Books, Lagos.

Akinlo, O. and Olufisayo M. (2005). Bank Credit and Economic Development: A Case Study of Deposit Money Banks. University of Jos. Jos.

Andrew, O. A. and Deborah, O. O. (2015). Development in Money Market Operations and Economic Viability in Nigeria Global Journal of Management and Business Research (GJMBR), Vol. 13, Issue 9.

CBN (2017). Statistical Bulletin, Abuja, Nigeria.

Chris, O. U. and Anyingang, R. A. (2012). The Effect of Interest Rate Fluctuation on the Economic Growth of Nigeria, 1970-2010.

Edo, S. and Ikelegbe, A. (2014). The Nigerian Economy: Reforms, Emerging Trends and Prospects. Centre for Population and Environmental Development, Benin City.

Edoumiekumo, G. S and Akarara E. A (2016). Non-Bank Financial Institutions versus Economic Growth: The Appulse in Nigeria. Wilberforce Journal of Social Sciences (WJSS), Vol.1(2): pp. 80 - 94

Eniekezimene, F. A (2012). Financial Institutions, Markets and Instruments, Harey Publications Coy: Port Harcourt.

Ezirim, C. B. and Eneta, F. E. (2006). Discount Houses, the Money Market and the Nigeria Economy. Economic and financial review, Vol. 41, No.3.

Fakiyesi, O. O. and Akano, S. O. (2005). Issues in Money, Finance and Economic Management in Nigeria. University of Lagos Press, Lagos.

Ihsan, I. and Anjum, S. (2013). Impact of Money Supply $\left(\mathrm{M}_{2}\right)$ on GDP in Pakistan. Journal of Third World Studies, Vol. 16: pp. 87-93

Iwedi,.M. and Igbanibo, D. S. (2015). The Nexus between Money Market Operations and Economic Growth in Nigeria. Quarter Journal of Economics, Vol. 119: pp. 717-738.

Muhammad, F. H and Berly, M. and Andi, M. A. P. (2015). The Contributions of Savings and Loans on GDP Growth: The Case of Indonesia. Journal of Development Economics, Vol. 84: pp. 215-233.

Nnana, O. J. and Dogo, M. (1998). Structural reform, monetary policy and financial deepening: The Nigerian experience, Economic and financial review, Vol. 36 No.2: pp. 1-29.

Nwude, C. E. (2004). Basic Principles of Financial Management. $2^{\text {nd }}$ Edition. Chuke Nwabude, Enugu, Nigeria. 
Pakistan Journal of Humanities and Social Sciences, 6(1), 2018

Ogunmuyiwa, M. S. and Ekone, A. F. (2010). Money Supply - Economic Growth Nexus in Nigeria. International Journal of Finance and Accounting, Vol.2(1): pp. 14-22

Pedro, S. A. and Erwan, .Q. (2004). The implications of capital-skill complementarity in economies with large informal sectors. Working paper in, Center for latin america, 0404, Federal Reserve Bank of Dallas.

Pesaran, M.H., Y. Shin., and Smith R. (2001). Bounds testing approaches to the analysis of level relationships, Journal of Applied Econometrics, Vol.16: pp. 289-326.

Rao Muhammad Atif, Abida Jadoon, Khalid Zaman, Aisha Ismail, Rabia Seemab (2010). Trade Liberalisation, Financial Development and Economic Growth: Evidence from Pakistan (1980-2009). Journal of International Academic Research Vol. 10, No.2: pp. 30-37

\begin{tabular}{|c|c|c|c|c|c|c|}
\hline \multicolumn{7}{|c|}{ Appendix } \\
\hline \multicolumn{7}{|c|}{ Correlogram of Residuals Squared } \\
\hline \multicolumn{7}{|c|}{ Included observations: 26} \\
\hline Autocorrelation & Partial Correlation & & $\mathrm{AC}$ & PAC & Q-Stat & Prob* \\
\hline.$|* * *|$ &.$|* * *|$ & 1 & 0.381 & 0.381 & 4.2175 & 0.040 \\
\hline$.\left.\right|^{*} . \mid$ &.$||$. & 2 & 0.194 & 0.057 & 5.3551 & 0.069 \\
\hline.$* 1$ & ***1. & 3 & -0.121 & -0.249 & 5.8193 & 0.121 \\
\hline .*1. & .*1. & 4 & -0.169 & -0.072 & 6.7677 & 0.149 \\
\hline .***| & .*1. & 5 & -0.270 & -0.151 & 9.2879 & 0.098 \\
\hline .*1. & $.1 \cdot 1$ & 6 & -0.129 & 0.028 & 9.8950 & 0.129 \\
\hline$.\left.\right|^{*} . \mid$ &.$|* *|$. & 7 & 0.110 & 0.224 & 10.361 & 0.169 \\
\hline .1 .1 & .*1. I & 8 & 0.057 & -0.143 & 10.492 & 0.232 \\
\hline$.\left.\right|^{*} . \mid$ & .1 .1 & 9 & 0.083 & -0.020 & 10.789 & 0.290 \\
\hline .*1. & . $* 1.1$ & 10 & -0.078 & -0.121 & 11.066 & 0.352 \\
\hline.$* 1.1$ & .*1. 1 & 11 & -0.189 & -0.187 & 12.806 & 0.306 \\
\hline.$* 1.1$ & .1 .1 & 12 & -0.201 & 0.054 & 14.906 & 0.247 \\
\hline
\end{tabular}

Source: Author's Computation 